\title{
ФОРМИРОВАНИЕ ГРАЖДАНСКОЙ ПОЗИЦИИ ОБУЧАЮЩИХСЯ ПОСРЕДСТВОМ ПОЭТИЧЕСКОГО ОБРАЗА (НА ПРИМЕРЕ ЛИРИКИ И. СУСЛОВОЙ)
}

Суслова И.Б. д-р. пед. наук, профессор

Аннотация: В статье автор раскрывает воспитательный потенциал поэтического слова на примере поэзии И. Сусловой, члена Интернационального союза писателей. Такие темы, как любовь к Родине, к природе родного края, сохранение исторической памяти, место человека в мире, человек и природа, преходящее и вечное в жизни человека, духовное познание и саморазвитие личности, воспитание чувства прекрасного содействуют совершенствованию этического, эмоционального, когнитивного, эстетического компонентов сознания обучающихся, способствуют формированию гражданской позиции студентов.

Ключевые слова: патриотическое воспитание, гражданская позиция, духовно-нравственное развитие, поэтическое творчество, педагогика, педагогическая технология.

Abstract: In the article the author reveals the educational potential of the poetic word on the example of poetry by I. Suslova, a member of the International Union of Writers. Such topics as love for the Motherland, for the nature of the native land, preservation of historical memory, the place of man in the world, man and nature, transient and eternal in the life of man, spiritual knowledge and selfdevelopment of the person, education of the feeling of the beautiful contribute to the improvement of the ethical, emotional, cognitive, aesthetic components of the 


\section{МОДЕРНИЗАЦИЯ СОВРЕМЕННОГО ОБРАЗОВАНИЯ:

consciousness of learners, contribute to the formation of the civic position of students.

Key words: patriotic education, civic position, spiritual and moral development, poetic creativity, pedagogy, pedagogical technology.

Поскольку воспитание человека направлено на формирование у него определенных ценностей, гражданское воспитание подразумевает формирование у человека ответственного отношения к себе, своей семье, к окружающим, к своему народу и Отечеству, к природе родного края и планеты в целом. Гражданин должен добросовестно выполнять не только конституционные законы, но и профессиональные обязанности, вносить свой вклад в процветание страны. Соответственно, в содержании понятия «гражданская позиция» в качестве определяющих целесообразно выделить ценностные аспекты с точки зрения проблемы социальной активности и гражданского становления личности. Ценностные компоненты сознания обучающихся формируются в процессе их духовно-нравственного саморазвития, Действенным средством здесь становится приобщение студентов к значимым в этико-философском значении циклам современной литературы, в частности, поэтического творчества. Поэзия, словесная образность наилучшим образом активизирует эстетический, эмоциональный, когнитивный компоненты сознания личности. Поэтические циклы И. Сусловой, члена Интернационального союза писателей, насыщены этико-философской, социально значимой проблематикой, в силу чего они могут стать эффективным средством формирования гражданской позиции обучающихся.

В тематике произведений автора можно выделить ряд смыслообразующих векторов, которые, будучи тесно взаимоувязанными, тем не менее, призваны активизировать разные ценностном отношении аспекты сознания личности. 


\section{МОДЕРНИЗАЦИЯ СОВРЕМЕННОГО ОБРАЗОВАНИЯ:

\section{1. Гражданская, патриотическая тематика}

Автор убежден: историческая память поколений - вот фундамент, на котором возводится будущее. Эта идея раскрывается в стихотворении «Герои Второй мировой: «/ Тебя вопрошают герои, Герои Второй мировой: / «Есть повод гордиться тобою? Есть право гордиться страной?» / Отцы вопрошают и деды, / Герои Второй мировой: / «К седьмому десятку победы / Порадуешь вестью какой?» / Родные, вестей подходящих / Для вас не найдет тот, кто жив. / И список без вести пропавших / Сегодня не вписан в архив. / Вы гибли, но приняли вместе / Последний свой праведный бой! / Забыли мы старые песни, / А новые - все вразнобой. / Но вновь вопрошают герои: / «Вы помните корни свои? / Готовы ли новое строить, / Как строили Спас-на-Крови? /» [5, С.135]. Современное общество духовно разобщено, констатирует поэт, в этом коренится исток многих проблем и опасностей для страны, в то время как единство целей и праведных устремлений придает народу небывалые силы [5, C.135].

Но в то же время, автора тревожит тенденция искажения истории, возможность забвения еe горьких и значимых для мировоззрения современников уроков. Поэтому крайне актуальное звучание обретают строки, пронизанные беспокойством за судьбы юношества, что находит свое отображение, например, в стихотворении «Ветер в лесу»: «Невероятное расскажет ветер, / Что было — не было на белом свете, / Взволнует деревце рассказом странным / - Оно поверило речам пространным! / Оно поверило, такое юное, / Да раскудрявое, да легкодумное. / И песни буйные поет вновь крона / За ветром-странником так упоенно. / Забыв, что Бога завет лесам, / Наказ, и строгий - заслон ветрам!/» [5, С.140]. В образе юного деревца прочитывается неокрепшее, подверженное влияниям извне мировоззрение молодого человека (девушки), что нередко приводит к весьма драматичным последствиям, но может иметь и трагический финал. Под ветром-странником, 


\section{МОДЕРНИЗАЦИЯ СОВРЕМЕННОГО ОБРАЗОВАНИЯ: ОПЫТ И ТЕНДЕНЦИИ}

завлекающим «легкодумную» молодежь своими «пространными речами» подразумеваются псевдо-оппозиционеры и провокаторы и пропагандисты разного толка, зарабатывающие на легковерии слушателей. В то же время, императив «заслон ветрам» четко сформулирован автором в качестве финального тезиса.

Гражданскую позицию личности во-многом формирует чувство любви к Родине, осознание своей причастности великой стране наполняет сердце гордостью: «/ Счастье великое русским родиться. Русича сердце умеет любить. / Главное только - с дороги не сбиться, Предков достойных заветы хранить /» («Россия») [5, С.136]. Научиться хранить заветы предков - это и означает научиться любить свою страну, служить ее интересам: «/ Вновь празднично, ярко, не строго / Шумит над планетой весна. / И много Вселенных, да, много, / Но только Россия одна! / Мелькают то весны, то зимы. / И в сердце - то холод, то, зной. / Но я об одном бы просила: Останься, Россия, собой! / Не дай твоим детям глумиться / Над вещею русской душой! / Пусть взгляд их к тебе обратиться - / Ты разум им дашь и покой. / Земля - небольшой, в общем, шарик / В сравнении с космосом всем. / А наша Россия - большая, / Она для души — насовсем! / И русской души позывные / Сойдутся в одном навсегда / Россия! Россия! Россия! / Ты — наша живая вода! /» («Родина») [5, С.134]. Родная страна - источник нескончаемых сил и духовного роста человека, любовь к России приобретает у автора воистину космический масштаб, в известном смысле полюбить Россию, свято чтить память великих ратных и трудовых подвигов предков - это и означает открыть в своем сердце родник «живой воды» любви и духовного благополучия.

Любовью к родным краям, к своей Отчизне проникнуты многие поэтические строки автора. Художественная образность этих циклов вызывает к жизни подобные чувства в душе читателя. Это можно сказать, например, о стихотворении «Лето в деревне»: «/ ...Там старушка колдует у печки. / Кладка 


\section{МОДЕРНИЗАЦИЯ СОВРЕМЕННОГО ОБРАЗОВАНИЯ:

дров, свежий сотовый мед / Есть в России такие местечки, / Где кукушка над лесом поет. / Остальное вы знаете сами - / Запах леса, кружит листопад. / Побывайте в деревне - часами / Можно в поле смотреть на закат. / Но грустна деревенская доля: / Здесь так мало осталось людей, / И такое пречистое поле, / Что на сердце грустней и грустней. / Где ты, Русь, за каким поворотом? / Или больше тебя не сыскать? / Но душа еще верит во что-то, / В то, что можно из пепла восстать // $[5$, С.131]. Как видно, средствами художественной выразительности раскрывается этико-философская подоплека стихотворения. Этому способствуют, например, мотив кукушки, поющей над лесом, образ «пречистого поля», вопросы автора к Руси (где ты, Русь, за каким поворотом?), метафоричность посыла надежды - «из пепла восстать» (сравнение Руси с птицей Феникс).

Художественная ткань стихотворения «Северный лес», вобрала в себя чувство душевного тепла, с которым автор говорит о родном крае, что призвано вызвать обратный отклик со стороны читателя: «/ ...Манящий зов - то запахи, то тени, / То колоннада сосен на пути, / И сотни мимолетных впечатлений, / И, как водица, солнышко в горсти. / Здесь птица с птицей в небе не столкнется, / Ковер из мха изысканно расшит. / Душа молчит, но эхо отзовется, / И с ней оно само заговорит. / И так понятен этот говор древний, / На целый век нам здесь остаться бы! / И так же манят домики в деревне, / Как белые душистые грибы /» [5, С.147]. Автор стремился передать ощущение уникальности, первозданности природы северного леса, ее красоты и хрупкости, посыл о необходимости бережного отношения к ценнейшему для человека ресурсу. К сожалению, леса России понесли серьезный ущерб в связи с неконтролируемой вырубкой, массивными пожарами, загрязнением и прочими неблаговидными плодами человеческой деятельности. Но чем в большей степени укоренится в общественном сознании стремление не допустить гибели наших лесных массивов, пресечь их преступное уничтожение, утвердится осознание 


\section{МОДЕРНИЗАЦИЯ СОВРЕМЕННОГО ОБРАЗОВАНИЯ:

уникальности и ценности леса, тем сохраннее будет природа российских регионов.

\section{2. Духовно-нравственная, этико-философская проблематика}

Если природа дарит жителям Земли радость, вдохновение и покой, то в душе самого человека кипят нешуточные страсти: «В ней, непроветренной и душной, взрастает семенем война! ...». «Море, небо — вот стихии, / -Те, что спорят век от века, / А раскаты грозовые — / В третьей — в сердце человека!», читаем мы в «Миниатюрах» [5, С.155].

Нежелание быть нравственно добрым, алчность, корыстолюбие и прочие пороки приводят мир к нескончаемым катастрофам: «/ Когда закончится война, / Которой нет конца и края, / По той причине, что она / Из края в край перетекает? /» - вопрошает автор в стихотворении «Вселенская вина» [5, С.127]. Конфликты человеческие в восприятии автора выходят на вселенский уровень, и вина за войны обретает статус вселенской. «/ Когда кончается война? — / Вопрос открытый, словно бездна. / Война — вселенская вина, / Искать виновных - бесполезно. /» [5, С.127]. Но автор призывает «искать управу на войну», т.к. ни каждый человек в отдельности, ни все человечество целиком не желают войны.

Каким же видится автору выход из ситуации перманентного противостояния, конфликтов и войны «всех против всех»? Следует обратиться к духовным источникам, стать на путь нравственного совершенствования: «/ Но как наполнить души светом, / Чтоб не померк наш белый свет? / Кто таинство откроет это, / Тот выполнит Творца завет!» [5, С.125].

Показательны в этом отношении следующие строки: «/ Твоя защита собственный твой дух, / Но только, чтобы был он страж надежный, / Всегда ты должен помнить непреложно: / Он - искра от костра, что не потух. /» (стихотворение «Блики огня») [5, С.124]. Что подразумевается здесь под костром, искрой которого является дух человека? Стихия костра трактуется 
двояко: «/ А тот костер - горение сердец, / Их поиск, их падения и взлеты. /», но также: «Мы - только блики Вечного огня, /», где подразумевается связь человека с Богом, с высшим духовным началом. «Мы - только блики Вечного огня, / Мы - только блики, / но огонь в ночи - морзянка сердца. / Пусть оно стучит, / И пусть в нем растворимся - ты и я!» - сердце как символ добра, чистоты помыслов, высшего блага - этот ориентир призван объединить человечество и избавить его от распрей и войн [5, С.124].

Многие поэтические произведения автора посвящены тематике духовных поисков, преображения, единения людей в истине и добре. Следующие строки в иносказательной форме призывают собеседника к духовности: «/ И лета золотой фиал / С тобой пригубив, глянем в выси, / Чтоб блеск его не затмевал / Сиянья благородных истин. / А будет осень, мы поймем, / Птиц наблюдая в поднебесье, / Когда мы истиной живем, / Тогда лишь мы, наверно, вместе /» $[4$, C.113].

Духовное развитие личности - вот путь, который вдохновляет автора. Эта тема раскрывается, например, в стихотворении «Горизонты сознания»: «/... Только, если ты юный, упрямый, / Если злостью хорошей ты зол, - / По дороге идти будешь прямо / И когда-то поймешь, что пришел. / Не свернул, не зевнул, не поверил / В удивительно сладостный плен, / Когда точно цветы на деревьях, / Видел головы юных сирен. / Горизонты сознанья расширив, / Ты поймешь - у всего есть свой рост. / Столько дел и чудес в этом мире, / Сколько в небе мерцающих звезд! /» [4, С.119]. Вознестись к вершинам и «познать пути дальних звезд» - вот цель саморазвития личности, полагает автор. Никто не обещает, что путь к себе, предполагающий реализацию своей жизненной миссии - это простой путь - он полон трудностей, искушений и соблазнов («головы юных сирен»). Но ведь везде «... / Идет сотворение / Новых чудес.», «...Где? В небе? А может, и в сердце моем, / Светло растревоженном звездным дождем! /» («Звездный дождь») [4, С.108]. 


\section{МОДЕРНИЗАЦИЯ СОВРЕМЕННОГО ОБРАЗОВАНИЯ:

Проблематика духовного развития крайне актуальна для современных обучающихся. Один из важнейших аспектов здесь - отсутствие ценностей, объединяющих людей, что характерно для цифрового общества. И если раньше для получения информации, реализации планов были нужны контакты и связи, человеческие отношения, то сейчас все заменяет сеть Интернет. Соответственно, у студентов все меньше потребность тренировать коммуникативные навыки - ведь для цифрового счастья достаточно поверхностного общения в Сети. Но когда утрачена глубина переживания межличностных отношений, люди превращаются в фантомы - за ними не стоят их жизненные истории. Однако издревле человек формировался как социальное существо, и по размеру стаи человекообразных обезьян биологи судят о развитости мозга. Тот же принцип действует и в человеческом обществе. Количество актуальных, значимых связей современников сократилось в разы, в результате чего само мышление человека становится поверхностным. «Когда технологии заменят живое общение, мы получим поколение идиотов», утверждал А. Эйнштейн.

\section{3. Философские размышления, духовные искания человека.}

Философские мотивы лирики И. Сусловой - это единство человека и мироздания, бесконечнось пути духовного развития человека, выявление связи природы и высшего божественного начала, духовные поиски преображения, единения людей в истине и добре . Наблюдение за природой часто перерастает у автора в философское созерцание, размышление над судьбами мира и человека: «/ Мы тоже, как волны морские, / И участь нам та же дана: / О берег скалистый, разбившись, волна / Останется частью стихии!» [5, С.156]. Автор повествует здесь о неразрывном единстве двух планов, духовного и физического.

Своими поэтическими разысканиями автор пытается дать ответы на многосложные вопросы человеческого бытия: что значит истина, время и 


\section{МОДЕРНИЗАЦИЯ СОВРЕМЕННОГО ОБРАЗОВАНИЯ:

вечность, любовь, красота, что такое духовное развитие, как человеку осуществить свою миссию на нашей планете. «/ Чтобы тебя природа приняла / Не в землю во сырую, а при жизни, / Возьми у вольной птицы два крыла — / Крылатые всегда нужны Отчизне. / Возьми у солнца теплоту луча, / Возьми у моря мощь его и силу, / И не руби, пожалуйста, с плеча, / А восходи над миром, как светило / Космизм не в моде? / Так не будь велик гиперболами всех сравнений звездных, / А будь таким, как под землей родник — / Пробьет скалу он рано или поздно. / Да, будь таким, чтоб жажду утолить / Того, кого своя пугает малость, / И так смоги ты сирого любить, / Чтобы для Бога про запас осталось / $>[5$, С.145].

В этих, во-многом, программных, с точки зрения замысла автора, строках в образной форме предстает путь духовного развития и самореализации личности - окрыленность мечтой должна обязательно подпитываться «теплотой солнечного луча» - благих помыслов и добрых дел, что позволит в конечном счете «взойти над миром, как светило». Настойчиво, «как под землей родник», без ложного величия, вобрав в себя «мощь и силу» природных стихий и силу собственного духа, человек должен пройти свой путь, помогая людям вокруг «утолить жажду» и словом, и делом.

К философскому созерцанию располагают завораживающие картины южной природы: «/ Кипарисы в паутине лунной, / Здесь дорога к морю. Вечереет. / Пусть земля не кажется нам юной / - С красотою сердце молодеет/». «/...Кипарисы в паутине лунной. Для меня и эта ночь, и грезы... Пусть земля не кажется нам юной - Вечные нас ждут метаморфозы! («Метаморфозы») [4, С.107]. В стихотворении просматривается вера автора в нескончаемый путь духовного развития человека. Образ кипарисов «в лунной паутине» вызывает к жизни сонм видений и образов - это мечты или «тень воспоминаний», размышлений о прошлом и будущем: «/ Прошлое вдруг станет настоящим, / Будущим - и все в судьбе единой /» [4, С.107]. Сам этот день сравнивается с 


\section{МОДЕРНИЗАЦИЯ СОВРЕМЕННОГО ОБРАЗОВАНИЯ:

кипарисом - «точно кипарис, высок и строен...». «Это мы уже переживали?» вопрошает лирический герой, увязывая воедино временные срезы и чувствования, пережитые и новые эмоции и мысли.

Вдумчивому наблюдателю природа открывает свои тайны, исцеляет душу своей самобытной красотой, а сознание проникает в суть бытийственных процессов: «/ Многосложна жизнь, я знаю. / В каждой капельке росы / Отразилась птичья стая, / Облака с речной косы /», /.. Многосложна жизнь, я знаю, / Каждый миг ее ловлю / И навеки провожаю, / Не забыв сказать: люблю! /(«Люблю»!)» [5, С.110]. И вновь любование природой и ее стихиями перерастает у автора в способ философского познания мироздания, а эпитеты восходят до уровня аллегорий: «/ И останется в нас медногривое лето, / Лето страсти вселенской, а мы / Сквозь алмазную пыль венценосносной зимы / Будем видеть пульсацию света. / Это сердце, которое бьется, любя - / Солнце вечной любви для меня, для тебя! .../ Той любви не вернуть, не украсть, не вкусить. / Остается одно нам - друг друга простить! / («Медногривое лето»)» $[3$, C. 155$]$.

Следующий философский мотив поэзии автора - это одухотворение природы, выявление связи природы и высшего божественного начала: «/ Не забудь посмотреть предвечерней порой, / Как прекрасна палитра небес, / Как задумчив пред тем, как уйти на покой / Подступающий к городу лес. / Эхо, облако, птица, вишневый закат / Очаруют и скажут без слов, / Что и миг быстротечный, и светлый наш сад / И судьба — все подарки богов!/» [5, С.138]. Стихотворение призывает читателя к наблюдательности, в нём прослеживается идея быстротечности жизни, ценности ее каждого мгновенья, необходимости бережного и трепетного отношения к природе, ко времени, дарованному человеку.

Образный ряд поэзии данного автора многогранен - помимо эстетического компонента, за ним прослеживается философский подтекст. 


\section{МОДЕРНИЗАЦИЯ СОВРЕМЕННОГО ОБРАЗОВАНИЯ: ОПЫТ И ТЕНДЕНЦИИ}

Получают свою интерпретацию такие темы, как глубинная связь человека и природы, взаимосвязь духовной ипостаси человека и божественного начала, духа и природы, творчество и сотворчество человека на Земле с Космосом, ответственность личности за плоды своего труда, ответственность перед собой, своей духовной сущностью, перед природой, обществом, человечеством. Автор призывает нас остановиться, пусть на мгновенье, среди суеты повседневных событий, прислушаться к себе и оглядеться вокруг: «... / Давно замеченный вселенский феномен - / Блестящий праздник - пустота и тлен. / Фигуры двигались, и музыка играла, / А близ дубрава тихая стояла. / Сбежав от утомленья, суеты, / Здесь с восхищеньем отмечаешь ты, / Что жизнь идет, стройна и вдохновенна! / Вот неизбывный феномен Вселенной! /» [3, С.124]. «Естества и очарованья» жизни нет в суетном времяпрепровождении современных обывателей, этого не найти, «напрасны и старанья», подмечает автор. Миру человеческой суеты здесь противопоставлена природа, где «тихая дубрава» оказывается наполненной живительными силами, дарующими внимательному наблюдателю покой и умиротворение.

\section{4. Поэтическое наблюдение за миром природы}

Основополагающими направлениями в данном содержательном блоке становятся: одухотворение мира природы, схожесть стихийных начал мира природы с эмоционально-чувственной сферой человека, природа как источник вдохновения, духовных и физических сил, гармонии и самопознания.

Природа в восприятии поэта полна тайны, динамики, движения, противоборствующих и примиряющихся начал, стихий и субстанций. Она призвана вдохновлять человека, давать ему жизненные силы, научать и совершенствовать. Автор как бы призывает всмотреться и вслушаться в нее, прочувствовать и слиться с ее жизненным одухотворяющим началом. Вот пример идиллической, умиротворяющей картины природы: «/ На побережье тихого залива / Остановилось время навсегда. / И в тишине молчит счастливо, / 


\section{МОДЕРНИЗАЦИЯ СОВРЕМЕННОГО ОБРАЗОВАНИЯ:

Мерцает зыбкая вода /» [5, С. 129]. В то же время, в стихотворении «Шторм» мы наблюдаем картину разбушевавшихся природных стихий: «/ А ветер толчет воду в ступе, / В гигантской, бесясь и визжа. / Видением смерча отступит / От порта морская душа! /» [5, С. 133].

Приобщение к миру природы помогает нам стать теми, кем мы являемся на самом деле, полагает автор: «/ Есть странная гармония стихий / В душе - и человека, и природы... / И, может быть, рождаются стихи, / Когда они в согласие приходят »/ («Шторм на побережье») [5, С. 102]. Поэтическая образность зачастую служит автору средством проникновения в таинства мироздания, инструментом философского осмысления его законов: «/ И как бы море не страшило, / Когда бушует, но оно / Для нас всегда - источник силы, / В нем божество заключено! /» [5, С.156]. Красота мироздания служит автору источником вдохновения, позволяет ощутить себя «творцом и сотворцом с единой жизнью»: «/ Сентябрь... полотно небес / Охвачено закатом - / Картина, полная чудес, / И пламенем объята! /»... «/ Живет и дышит, и горит, / Горит, но не сгорает, / О сокровенном говорит / И тайны раскрывает. / И чувствуешь себя творцом, / А сердце искрой алой / Под этим огненным венцом, / Взметнувшимся порталом /» («Закат в сентябре») [4, С.103].

Рассмотрим, стихотворение под названием «Музыка леса»: «Леса храм, там, где сосны - колонны, / Пахнет ладаном - хвои настой. / Мир еще молодой и зеленый, / И в вечерних лучах - золотой. / Лес - орган, ветерок это знает, / Вторят музыке солнца лучи, / Виртуозно ноктюрн исполняют, / Он и в небе, и в сердце звучит!/» [5, С.97]. Помимо ощущения легкости, музыкальности, читателю передается чувство сакрального благоговения перед стихией леса, которым проникнуты строки: «леса храм», «сосны-колонны», «пахнет ладаном». Выходя на уровень скрытых обобщений, автор утверждает - лес - это мир, ведь сразу после следуют строки: «Мир еще молодой и зеленый, И в вечерних лучах - золотой». По авторскому замыслу, стихотворение должно 


\section{МОДЕРНИЗАЦИЯ СОВРЕМЕННОГО ОБРАЗОВАНИЯ:

вызывать к жизни чувство любви к лесу, осознание непреложной важности ресурса леса для жизни на Земле, необходимости беречь леса планеты. «Ноктюрн», «исполняемый лесом», звучит и в небе, и в сердце - не только красота и великолепие лесов восхищают автора, их музыка, поэтичность, но и, в первую очередь, их сакральность, значимость для жизни человека.

Однако природа не всегда гармонична и благостна для человека: порой она опасна, грозна, но всегда величественна и всегда порождает отклик в нашей душе, на контрасте с ее стихиями и проявлениями рождаются новые чувства и поэтические образы. Это происходит, например, в стихотворениях, где солнце и лето предстают в демонизированном, недружелюбном облике, словно бы в состоянии противоборства с лирическим героем-путником: «/ Лето смеется заржавленным ртом / Словно сто тысяч ветров. / Оно по земле идет босиком / В царстве трав и цветов /». В образе путника-странника автор выводит творца, художника, мыслящего человека, который проходит свой Путь, свободный в своих творческих поисках «от пут и оков» рутинного, заскорузлого мировосприятия: «/ Тот, кто по гривам гладил коней, / За летом отправился в путь. / Свободен от ноши и от цепей, / Придет он куда-нибудь. / Дерзкий, он слышит звездную речь, / Он им отвечает сам / Легко клубок расставаний и встреч / Доверил он небесам /...» [5, С.105].

Подобный художественный прием мы можем наблюдать в следующем стихотворении: «/ Вздрогнет зверь, отзовется долина / за прищуром холодных времен. / Ветер выгнет шершавую спину / Огнедышащей песней пламен /». Здесь мы опять же встречаем образ путников-творцов, разбредшихся «по дремотной зиме» в поисках истины и вдохновения: «/ Разбежится крутая дорога / И упрется в холодную высь. / Много путников, много и много / По дремотной зиме разбрелись /» [5, С.114]. Примечательно, что их творческий путь не протекает гладко, он тернист, о чем говорят образы, обрамляющие мотив путников: «прищур холодных времен», «шершавая спина ветра», театральное, 


\section{МОДЕРНИЗАЦИЯ СОВРЕМЕННОГО ОБРАЗОВАНИЯ:

беспощадное, похожее на гигантского паука, солнце: «/ И бесстыжее солнце лизало / Горный щебень своим языком / И по небу лениво сползало / Яркобрюхим стальным пауком /» [5, С.114].

И все же, в большинстве стихотворений и поэтических зарисовок автора природа гармонична, удивительна в своей красоте, в том жизненном и творческом посыле, который она снабжает человеку: «/ Порой такая тишина / И мягкий свет в саду осеннем / Как будто говорит она, / Что в ней одной найдешь спасенье. / Как глупо быть распятым злобой / Что в глубине души взросла, / И, собственной гордясь особой, / Забыть, что осень так светла! .../» [5, С.118].

Как видно, посредством приобщения к миру художественной образности поэта, эстетический, этико-философский и когнитивно-мотивационный компоненты сознания обучающихся могут получить дополнительный стимул к активации и развитию, что, несомненно, способствует формированию гражданской позиции личности. И если приять во внимание тезис И. Канта о том, что педагогика является искусством, то его смысловые рамки можно расширить до следующего утверждения: педагогика уникальным образом пересекается, взаимопроникает с искусством в таких ее разделах, как психолого-педагогическая антропология, педагогическая психология, теория и методика воспитания.

Следующий философский мотив поэзии автора - это одухотворение природы, выявление связи природы и высшего божественного начала: «/ $\mathrm{He}$ забудь посмотреть предвечерней порой, / Как прекрасна палитра небес, / Как задумчив пред тем, как уйти на покой / Подступающий к городу лес. / Эхо, облако, птица, вишневый закат / Очаруют и скажут без слов, / Что и миг быстротечный, и светлый наш сад / И судьба - все подарки богов!/» [5, С.138]. Стихотворение призывает читателя к наблюдательности, в нём прослеживается идея быстротечности жизни, ценности ее каждого мгновенья, необходимости бережного и трепетного отношения к природе, ко времени, дарованному человеку. 


\section{МОДЕРНИЗАЦИЯ СОВРЕМЕННОГО ОБРАЗОВАНИЯ: ОПЫТ И ТЕНДЕНЦИИ}

Образный ряд поэзии данного автора многогранен - помимо эстетического компонента, за ним прослеживается философский подтекст. Получают свою интерпретацию такие темы, как глубинная связь человека и природы, взаимосвязь духовной ипостаси человека и божественного начала, духа и природы, творчество и сотворчество человека на Земле с Космосом, ответственность личности за плоды своего труда, ответственность перед собой, своей духовной сущностью, перед природой, обществом, человечеством. Автор призывает нас остановиться, пусть на мгновенье, среди суеты повседневных событий, прислушаться к себе и оглядеться вокруг: «... / Давно замеченный вселенский феномен - / Блестящий праздник - пустота и тлен. / Фигуры двигались, и музыка играла, / А близ дубрава тихая стояла. / Сбежав от утомленья, суеты, / Здесь с восхищеньем отмечаешь ты, / Что жизнь идет, стройна и вдохновенна! / Вот неизбывный феномен Вселенной! /» [3, С.124]. «Естества и очарованья» жизни нет в суетном времяпрепровождении современных обывателей, этого не найти, «напрасны и старанья», подмечает автор. Миру человеческой суеты здесь противопоставлена природа, где «тихая дубрава» оказывается наполненной живительными силами, дарующими внимательному наблюдателю покой и умиротворение.

Природа в поэтических подборках автора одухотворена, наполнена волшебными красками и звуками, это настоящий храм, куда человек должен входить как служитель и сотворец, благоговея перед этим сакральным миром, черпая в нем свое вдохновение и учась у него, постигая его бесконечные тайны./.. Там рождается музыка — эхом ночным / За вечерней морскою волною. / Легких клавиш касается, тает как дым, / Вновь колдует над вещей струною. /» [6, С.107]. Ярким примером одухотворения природы могут послужить следующие строки: «А ночь была та — тише сна. / Вдруг — легкий вздох. Не спит сосна, / И с неба - сонмы водных стрел, / Дождь благодатный прошумел./» [5, С.141]. В этом стихотворении, имеющем название 
«Обновление», создан динамичный образ обновления природы парка после ночного дождя - «вздыхающая» сосна, внезапно прорывающие тишину ночи «сонмы водных стрел» придают мотиву движение, жизненный динамизм, преображение: «Сияющий природы лик Прекрасен. / Значит ночь забыта. /». Эти метаморфозы созвучны с переменами, происходящими в душе лирического героя: «И обновление в душе, / И чувство светлое такое, / Как осень, что пришла уже, / Нам дарит золото покоя /» [5, С.141].

Таким образом, в поэзии автора звучат такие темы, как любовь к природе родной страны, чаяние о судьбах природы России, о судьбах русской деревни, тема борьбы добра и зла в душе человека, поисков высших начал и оснований человеческого бытия, неразрывности творческого и философского поиска с наблюдением за жизнью природы. Посредством приобщения к миру художественной образности поэта, эстетический, этико-философский и когнитивно-мотивационный компоненты сознания обучающихся могут получить дополнительный стимул к активации и развитию, формирования гражданской позиции личности. Поэтические циклы И. Сусловой могут быть использованы в этико-педагогических целях в образовательном пространстве вуза. Актуально звучит сегодня патриотическая, морально-нравственная философско-мировоззренческая проблематика. Материалы поэтических сборников автора могут быть включены в курсы культурологии и других гуманитарных дисциплин в качестве дополнения к тематическим повесткам семинарских и факультативных занятий, круглых столов и прочих мероприятий познавательного и развивающего характера.

\section{Список литературы}

1. Кант И. Собрание сочинений в 8 томах. Т.4, 6. М.: ЧОРО. 1994

2. Кант И. Собрание сочинений в 8 томах. Т.4: Основоположения метафизики нравов. М.: ЧОРО. 1994 
3. Суслов Н., Суслова И. Земляника: стихи. Киров: КОГУП «Кировская областная типография». 2001 г. 160 с.

4. Суслов Н., Суслова И. Нить Ариадны: стихи. Сочи. Изд-во «Дория». 2002 г.

5. Суслов Н.А., Суслова И.Б. Солнечный берег. Литературнохудожественное издание. Сочи, ЗАО «Дория». 2005 г. 160 с.

6. Суслова И.Б. Аксиология образования и этическое самовоспитание обучающихся. Сочи. «Оптима». 2019 г.

7. Суслова И.Б. Воспитательный потенциал современной поэзии (на примере лирики И. Сусловой). Гуманизация образования. 1/2021. С. 92-99.

8. Beckmann Tino. Mentoring in schulischen Praxisphasen. Praxisbuch. Böhlau. Verlag Vien-Köln-Weimar, 2021

9. Bender Saskia / Rennebach Nils. Teilhabeordnungen inklusiven Unterrichts. Zeitschrift für Pädagogik. Beltz Juventa. Ausgabe 2, Jahr 2021, Seite 231 $-250$

10. Dainton Nora. Feedback in der Hochschullehre. Böhlau Verlag Vien-KölnWeimar, Hauptverlag, 2018

11. Damberger Thomas. Bildung und Erziehung heute. Eine erzählerische Hinund Einführung. Beltz. Juventa in der Verlagsgruppe Beltz, Weinheim Basel, 2021

12. Karber Anke. Praktiken der Reflexion in pädagogischen Qalifizierungen Forschungs- und Entwicklungsanfragen. Bildung und Erziehung. Vanderhoeck \& Ruprecht Verlage. Jg. 74, Heft 2, 2021

13. Roland Reichenbach. Ethik der Bildung und Erziehung. Originalverlag Schöningh, Auflagennr.1, 1 Aufl., 2017

14. Su Hanno / Bellmann Johannes. Inklusive Bildung und die pragmatische Maxime der Gleichheit. Zeitschrift für Pädagogik. Beltz Juventa. Ausgabe 2, Jahr 2021, Seite $275-294$.

15. Pind-Roßnagl Susanne. Lesson Studies und Learning Studies als Schulentwicklungsberater/in initiieren und begleiten. 